\title{
Halal Tourism Marketing in the Disruption Era: A Case Study of Penyengat Island in Riau Islands Province
}

\author{
Riska Destiana ${ }^{1, *}\left(\mathbb{D}\right.$, and Kismartini Kismartini ${ }^{1}$ (iD) \\ ${ }^{1}$ Master of Public Administration, Department of Public Administration, \\ Faculty of Social and Political Sciences, Diponegoro University, 50241, Semarang, Indonesia \\ * Corresponding Author: destiana.riska1812@gmail.com
}

\section{ARTICLE INFO}

Publication Info:

Literature Review

How to cite:

Destiana, R., \& Kismartini, K. (2020). Halal Tourism Marketing in the Disruption Era: A Case Study of Penyengat Island in Riau Islands Province. Society, 8(1), 264-283.

DOI : 10.33019/society.v8i1.174

Copyright $\odot$ 2020. Owned by Author(s), published by Society

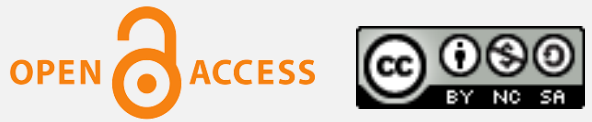

This is an open-access article.

License: Attribution-

NonCommercial-ShareAlike (CC BY-NC-SA)

Received: May 3, 2020;

Accepted: June 8, 2020;

Published: June 30, 2020;

\section{ABSTRACT}

The disruption era creates great opportunities for halal tourism development by using technology to market halal tourism products. As a pilot project for the halal tourism development, Penyengat Island in Riau Island Province faces the challenges in building its image as a leading halal tourism destination. This study aims to analyze the halal tourism marketing, in this case, digital marketing, on Penyengat Island in the disruption era. This research used descriptive qualitative methods through a literature study with data sources derived from related journal articles and other literature. The efforts of halal tourism marketing for Penyengat Island are not implemented digitally. To market tourism of Penyengat Island, the local government and stakeholders use mass media advertising, billboards, annual festivals, and digital channels such as social media, online booking sites, and e-book guides at halaltrip.com. Yet, the media does not inform tourism events or indicate Penyengat Island as a halal tourism destination. It proves that inadequate information about the concept of halal tourism and/or other available information on halal tourism travel guides for Muslim tourists on the digital platforms used. The efforts to promote Penyengat Island as halal tourism using digital channels are the relevant interesting contents in digital marketing channels, the availability of information on the need for halal services, and innovation on tourism attractions.

Keywords: Digital Marketing; Disruption; Halal Tourism; Information; Penyengat Island

Copyright $($ 2020. Owned by Author(s), published by Society. This is an open-access article under the CC-BY-NC-SA license. 


\section{Introduction}

The Industrial Revolution 4.0, or known as the disruption era, produced dramatic changes in the way of life, work, interaction, and brings certainty to the speed, breadth, and depth of information and innovation (Pujayanti, 2020). Digital disruption takes place when players in the old industry face new challengers that offer greater value to customers through ways in which the old industry cannot compete directly (Purcărea \& Purcărea, 2017).

The disruption era led to disruption technology which was considered as a new business strategy approach through technological use and an emphasis on market value. The existence of disruption technology will bring various innovations, which are to identify and recognize the changes in technology and consumer needs (Putra, 2018).

Disruption also raises the digital economy, an economy that is based on digital computing technologies and network effects. The internet offers a wide range and rich information for business transaction processes. Renald Khasali as cited in Roziqin (2019) stated that the meaning of disruption is also emphasized on business fundamentals (from the cost structure to culture) as well as sharing the economy, the roles, and collaborating.

The disruption era impacts almost all aspects of life. Tourism is one of the sectors that is the most impacted since the era provides challenges and opportunities for the world of tourism to adapt and take advantage of the momentum of change in the development of tourist destinations. In recent years, tourism in Indonesia has played an important role because it has the potential to become the second-largest foreign exchange earner after Crued Palm Oil or CPO (Liputan6.com, 2019).

The number of foreign tourists visiting Indonesia shows an upward trend from year to year and is dominated by tourists from Malaysia, China, and Singapore. In 2015, the number of foreign tourist arrivals was around 10,230,775 tourist, in 2016 around 11,519,275 tourists visited, in 2017 the number increased to 14,039,799 tourist, in 2018, it increased to 15,810,305 tourist and in 2019 around 16,106,954 tourist came to visit Indonesia (Badan Pusat Statistik, 2020).

Halal tourism is one of the tourism segments that are being developed in Indonesia that provides facilities for the basic needs of a Muslim tourist, such as religious facilities, halal food, toilets equipped with water taps, and supporting facilities under sharia law in the tourism destinations. According to DinarStandard \& Dubai International Financial Centre (2018) in "An Inclusive Ethical Economy, State of the Global Islamic Economy Report 2018/19" stated that Muslim spending on halal tourism is USD 177 trillion in 2017, and is projected to increase amounting to USD 274 trillion in 2023. So, halal tourism is considered to have great potential in the tourism industry.

Since 2015, the Ministry of Tourism and Economy Creative of the Republic of Indonesia has been developing halal tourism. In 2018, the growth of the halal tourism market in Indonesia reached 18\%, with the number of Muslim foreign tourists reaching 2.8 million, and the foreign exchange generated reached more than Rp 40 trillion. The phenomenon of new market growth in the world of tourism in Indonesia, the Ministry of Tourism is targeting foreign tourist arrivals of $25 \%$ of the 20 million foreign tourist arrivals target in 2019, or equivalent to 5 million foreign Muslim tourists (Kementerian Koordinator Bidang Kemaritiman dan Investasi Republik Indonesia, 2019).

The tourism sector faces challenges in technology during the disruption era. The advances in information communication technology (ICT) resulted in the loss of intermediaries in the travel agent marketing chain. Nowadays, tourists can create their own travel experiences using online travel agents by combining smart gadgets, mobile commerce, location-based services, 
and sharing economy. The smart tourism concept is used by stakeholders through technological use in sharing information about tourist experiences (Hsu et al., 2016).

The Ministry of Tourism of the Republic of Indonesia nominated Penyengat Island as a pilot project in the area of halal tourism development in Riau Islands Province. The Ministry of Tourism expects the designation of Penyengat Island can encourage the acceleration of halal tourism development because it is located in the strategic location of the Riau Islands as an entry point for foreign tourists, especially since the main market share of tourists is dominated from Singapore and Malaysia (Indonesiatravel.news, 2019)

Penyengat Island which is included in the administrative area of Tanjungpinang City, through the Minister of Education and Culture of the Republic of Indonesia Decree Number 112/M/2018 in 2018, nominated as the National Cultural Heritage Area and is regulated through Tanjungpinang City Regulation Number 8, Year 2018 concerning Management of Penyengat Island Cultural Tourism. Penyengat Island has an important attribute as the center of Islamic Malay studies. Also, Penyengat Island is the birthplace of Malay grammar (the basis of Malay grammar which is then called Indonesian). Penyengat Island is strategic because it is in direct opposition to Singapore and Malaysia, supports the potential for professional tourism development. Historically, Penyengat Island in the past time has an inseparable relationship with Singapore and Malaysia which was under the empire of the Riau Lingga Malay Kingdom (Zahra, 2019).

As a tourism destination area, foreign tourists are targeted from Singapore and Malaysia, which is required to conduct intensive promotions to attract tourists to visit. The halal tourism segment that is being developed should be an opportunity to attract Muslim and non-Muslim tourists from neighboring countries because halal tourism is a form of tourism with extended service. Tourism promotion in the technological disruption era as it currently relies heavily on creativity, innovation, technological sophistication, and collaboration between stakeholders. This can be applied to its development on Penyengat Island considering its main market share is foreign tourists who want ease in accessing the information on a tourism destination. Sigala (2018) mentioned that technology has a large impact on consumer behavior, decision-making processes, planning, and tourism experience. Technology not only changes the way tourists identify, select, pay for, and enjoy the tourist experience, but also changes the motivation of traveling.

The disruption era has brought many changes in the tourism world, especially for marketing tourist destinations. Musthofa (2019) stated that the use of digital facilities as communication media for promotion, marketing, and education through various digital platforms that are positive for the development of cultural tourism offered by Saung Angklung Udjo. The creativity and setbacks faced are very important in the process of tourism product development, so they can survive and continue to grow amid changes, and ultimately have an impact on increasing tourist visits. Balasubramanian \& Ragavan (2019) also stated that technology has brought a significant impact on the tourism industry and hospitality, also requested service changes to meet the millennial consumer needs and the global market.

Buhalis (2019) claims that technology supports shared interests in the tourism ecosystem. The tourist experiences with the development of technology facilitate tourists to recreate values through traveling steps. Hsu et al, (2016) said that the education sector faces competition as a result of disrupted technology. The development of new travel models requires innovative business solutions, such as product digitization, sharing economy adoption, and strengthening the collaboration between stakeholders. 


\section{Halal Tourism Marketing in the Disruption Era: A Case Study of Penyengat Island in Riau Islands Province}

MasterCard-CrescentRating in "Digital Rating Muslim Travel Report 2018" predicts Muslim tourists will spend USD 180 trillion in 2026 for booking trips through the online system (MasterCard \& CrescentRating, 2018). Public dependence on the internet due to the condition of the Internet of Things (IoT) will shift people's behavior patterns gradually towards something more practical and faster. The changes in markets and technology encourage producers to carry out different expansion strategies through online platforms and other media companies (Roziqin, 2019).

From some studies above it can be concluded that the disruption era has changed the tourism industry in an adjustment to capture market tastes through the use of technology. The use of technology has changed the world of tourism, both in tourist demand, business strategies that must be adjusted, and the innovation of tourism products and the ease of digital marketing that has the potential to attract even more tourists. Penyengat Island, as a tourism destination, has been developed the tourism programs by the local government for many years (Zahra, 2019). The concept of halal tourism for Penyengat Island is still relatively new developed. It is a driving force that can contribute to improving the quality of tourism in the island. Moreover, in an era where technology plays a very significant role, it must be considered as a tourism marketing opportunity that is greater and can reach more tourists to visit. Therefore, this research is to analyze how halal tourism marketing of Penyengat Island in the disruption era.

\section{Literature Review}

\subsection{Disruption Era}

The disruption era is a digital revolution since the proliferation of computers and the automation of records in all fields. Industrial Revolution 4.0 is the era of technological disruption because automation and connectivity in a field will move the industrial world and job competition become non-linear. To promote and market products, information, and communication technology are a very effective medium (Musthofa, 2019). According to Christensen (1997) as cited in Hadiyat (2019) disruption era is a new technological innovation both products and services that disrupt technology establishment which gives birth to some new industries. Disruption technology rises to various innovations, both positive and negative.

Purcărea \& Purcărea (2017) mentioned several concepts of disruption. Digital disruption presents some challenges for old industries against new competitors that bring greater value to consumers through the ways where old industries cannot compete directly. To engage digital consumers effectively and involve the touch in the circle of consumer experience, an industry must transform the digital change as a new investment process in technology and business models. Industries must change their production processes so that customers easily access the information. The disruption innovation will emerge based on technology starting from the bottom end of the market or creating new market steps.

The 4.0 industrial revolution brings the changes of the people's economy. Digital developments make it easy to access the changes in people's economic behavior. Businesses will survive when they can take advantage of technological changes. The business model approach has transformed from the owning economy model to a sharing economy that impacts on smaller production capital and consistent profitability. The vast marketing area that users can reach will open greater opportunities. In such an environment, none can move and walk by oneself rather than the need for collaboration between actors (Roziqin, 2019).

Various definitions of the disruption era have been found through various sources, it can be concluded that it is marked by the changes of business strategy in meeting the needs of consumers through the use of information technology. The era of disruption is also

Copyright (C 2020. Owned by Author(s), published by Society. This is an open-access article under the CC-BY-NC-SA license. https://doi.org/10.33019/society.v8i1.174 
characterized by an economic system change from owning economy to sharing economy, which certainly strengthens the fabric of collaboration that must be carried out between relevant stakeholders so that the business strategy undertaken to meet market demands for information and access convenience. Innovation is also important in facing the era. Innovations can forecast and deal with the market changes to meet consumer needs as it is affected by the development of increasing massive technology.

\subsection{Tourism}

World Tourism Organization and the Inter-Parliamentary Union in 1989 stated that the concept of tourism as "it encompasses all free movements of persons away from their places of residence and work, as well as the service industries created to satisfy the needs resulting from these movements" (WTO, 1989 as cited in Happ \& Ivancsó-Horváth, 2018).

Michalkó (2001) as cited in Happ \& Ivancsó-Horváth (2018) described that "tourism is an individual's experience, associated with an environmental change, where services are used". Cook et al, (2014) as cited in Battour \& Ismail (2016) stated tourism as "the temporary movement of people to destinations outside their normal place of work and residence, the activities were undertaken during their stay in those destinations, and the facilities created to cater to their needs".

Kotler and Armstrong (1997) as cited in Ratu \& Adikampana (2016) stated the marketing strategy is the marketing mindset used by business units to achieve marketing objectives. Components of the marketing mix according to McCarthy as cited in Kotler (2000) are products, prices, places, promotions (Ratu \& Adikampana, 2016). Tourism marketing is all activities to identify the needs and desires of tourists so that they can provide maximum service to tourists (Yoeti, 1985, as cited in Ratu \& Adikampana, 2016).

Tourism marketing activities aim to persuade tourists who are categorized into two groups, namely first, groups of people who have financial and physical abilities for tourism activities but do not have time to travel; the second group is tourists who are the target of promotion for information giving and influence tourists who are considered to have prospects to visit tourist destinations (Afifatur \& Novaria, 2017 as cited in Rohimah \& Romadhan, 2019).

A successful tourism destination marketing framework requires a cooperative and strategic approach. With this approach, four important things must be done, namely forming a tourism destination marketing committee; developing a strategic tourism destination marketing plan that is in line with the existing tourist destination development plan; conduct relevant research; and identifying and developing new tourism products and experiences (Cox \& Wray, 2011).

Laws (1995) as cited in Cox \& Wray (2011) develops a marketing planning framework for tourism destination into five phases, they are:

1) In the initial phase, tourist destinations must assess the market situation including audits of existing tourist facilities, identify tourist preferences and behavior regarding tourist destinations, and identify competing tourist destinations;

2) This phase is a process related to the plan for developing tourist destinations;

3) Establishing destinations for regional tourist destinations;

4) Implementing a marketing strategy;

5) Observing marketing performance.

\subsection{Halal Tourism}

Battour \& Ismail (2016) explained that halal tourism is all tourist objects or actions that are permitted according to Islamic teachings as expected by Muslim tourists in the tourism 


\section{Halal Tourism Marketing in the Disruption Era: A Case Study of Penyengat Island in Riau Islands Province}

industry. Islamic law is considered as a base for distributing tourism products and services to targets mostly Muslim consumers such as halal hotels, halal resorts, halal restaurants, and travel under Islamic values. Tourist sites are not only in Muslim-majority countries but also can be applied in Muslim minority countries. Therefore, halal tourism includes tourism services and products designed for Muslim tourists in Muslim or non-Muslim countries. Furthermore, the definition considers tourist destinations not only focusing on religious tourism but also on motivation and other general tourist destinations.

Razzaq et al, (2016) reported that Muslim tourists tend to choose Sharia accommodations that have attributes such as the availability of halal food, the appropriateness of hotel staff uniforms, the absence of pornographic content images and alcoholic drinks, information on nearby mosques for Friday prayers, meeting room with worship facilities. The increasing demand for commercial tourism and hospitality services that adhere to Islamic law is described as "halal tourism", "halal hospitality", "Islamic tourism" or "Islamic tourism" (Henderson, 2010 as cited in Razzaq et al., 2016; Carboni et al., 2014 as cited in Razzaq et al., 2016).

Halal tourism is a new concept in the tourism industry that offers packages and tourist destinations designed to serve the needs of Muslim tourists (Asazuma, 2015 as cited in Wahidati \& Sarinastiti, 2018). Permanent Committee for Economic and Commercial Cooperation the Islamic Cooperation Organization (Wahidati \& Sarinastiti, 2018) calls halal tourism with the term Muslim-friendly Tourism (MFT) and define it as "Muslim travelers who do not wish to compromise their basic faith-based needs while traveling for a purpose, which is permissible", or it also is defined as "halal conscious travelers, traveling for any purposes, which is halal (permissible)".

The definition of halal tourism must be carried out of various aspects. From the definitions above, it can be concluded that halal tourism is a tourism concept that offers additional services, to meet the Muslim basic needs based on Islamic teachings. The concept emphasizes on offering additional services; it means that halal tourism is not only about religious tourism, but also the concept of all tourism in general. Although Muslim as the main target, halal tourism industry managers must innovate offering tourism attractions to attract them coming to the destination. The concept of halal tourism broadens the target of tourists since comfortable for Muslim tourists in tourist destinations is a priority.

\subsection{Halal Tourism Marketing in the Digital Era}

Internet marketing is the process of building and managing relationships with consumers through the exchange of ideas, products, and services that satisfy consumers. Digital marketing is the use of digital technology that aims to create integrated, targeted, and measurable communications that help to obtain and retain consumers while building close relationships with them (Roziqin, 2019).

Kaur (2017) stated that the success of digital business marketing activities in the tourism industry is determined by the following points, including a quality website, a strong social media presence, search engine optimization, e-mail marketing, attractive content, and mobilefriendly. In another study by Happ \& Ivancsó-Horváth (2018) the term concept of smart tourism states that there are three main components, based on information communication tools, including smart destinations, smart experiences, and smart business systems. Buhalis (2003) as cited in Happ \& Ivancsó-Horváth (2018) who mentioned the concept of e-tourism as digitizing the entire process chain and values in tourism, travel, and hospitality to maximize effectiveness and efficiency. Digital tourism is interpreted as the use of information communication tools, an

Copyright ( ) 2020. Owned by Author(s), published by Society. This is an open-access article under the CC-BY-NC-SA license. 
IT solution that can help find the needs of tourists and increase organizational and business competition in tourism.

In the tourism industry, digital marketing provides information through different channels to reach their potential consumers, by providing reliable and always updated information. Providing a website as a digital tourism marketing channel must also make it easier for tourists to obtain information. Social media for the tourism industry is very important because tourists' decisions to take a vacation to depend on the experience, reviews, and feedback from trips made by others. Besides e-mail is considered effective as a place of direct interaction with tourists, and can track and analyze user behavior on the website (Gupta, 2019).

Tourism marketing in the digital era encourages tourism resources to make the most of technology. Changes in tourist behavior that are reflected in the stages of travel planning travel decision making to experience during the trip, affect the management of the tourism industry to provide an effective channel for tourists to access as much information about the tourist destination to be addressed. The use of websites, social media, e-mail, to mobile-friendly applications is the choice in marketing tourist destinations to attract tourists, of course with quality content and easy access to information for tourists.

Yousaf \& Xiucheng (2018) stated that eight dimensions in the marketing of halal tourism, including the ease of finding halal products and services; halal assessment and certificate; Halal food features; Halal food restaurant recommendations; Improvement of halal tourism experience; Halal as a symbol of culinary differences; the halal aspect at the airport; Additional halal services and facilities.

Idris \& Rahman (2018) mentioned that a report published by the Statistical, Economic and Social Research and Training Center for Islamic Countries (SESRIC) in 2017 included an effective marketing strategy in the tourism sector, which was then utilized to analyze key marketing concepts in Islamic tourism, consisting of:

1) Developing product refers to the creativity of Islamic tourism products and services with new or different characteristics that offer new or different benefits to tourists;

2) Branding, a process that involves creating a unique name and image for Islamic tourism products, places, and services in the minds of tourists, especially through ad campaigns with consistent themes;

3) Pricing, activities in finding the best prices of tourism products and services;

4) Positioning, an Islamic tourism marketing strategy that aims to create an image of a country, city or region occupying a different position, relatively for a competitive image in the minds of tourists;

5) Promoting, the advancement of products, services or places of Islamic tourism through publication or advertising

Battour \& Ismail (2016) mentions several attributes that support halal tourism in attracting more visits and serving the needs of Muslim tourists, including:

1) Availability of the mosque;

2) Availability of worship facilities on tourism sites, airports, hotels, and other public places;

3) Availability of Azan (call to prayer), or a call for worship time;

4) Availability of Qibla guidance;

5) Availability of water in toilets at airports, tourist sites, shopping areas, and others;

6) Availability of halal food at airports, tourist sites, shopping areas, and others;

7) Availability of separate halal kitchens in hotels and restaurants;

8) Availability of a separate area for women on the beach

Copyright (C 2020. Owned by Author(s), published by Society. This is an open-access article under the CC-BY-NC-SA license. https://doi.org/10.33019/society.v8i1.174 
9) Availability of separate swimming pools and sports venues;

10) Prohibition of alcoholic drinks with authority in public spaces;

11) Prohibition of sexual content channels in the hotel entertainment system

Research on digital marketing for halal tourism development has not been carried out optimally. Yousaf \& Xiucheng (2018) observed the halal tourism marketing digitally only through the government website channel although it was mentioned the halal tourism marketing dimension, whereas according to Kaur (2017) the success of digital tourism marketing aside from a quality website, it was also supported by the presence of strong social media, search engine optimization, e-mail marketing, attractive content, and mobile-friendly. In this research, the concept of digital marketing of halal tourism combines the concept of digital tourism marketing according to Kaur (2017) which puts forward website channels, social media, interesting and mobile-friendly content, with the attributes of halal tourism marketing according to Yousaf \& Xiucheng (2018).

\section{Research Methodology}

This research used a qualitative descriptive method with library research or literature review by utilizing relevant articles related to the research topic (Hadi, 1995). This research focused on the development of Penyengat Island as halal tourism, in Riau Islands Province specifically in tourism marketing during the disruption era. Data collection techniques were documentation. Data were collected from February to April 2020, using Facebook, Instagram, YouTube, Traveloka, Tripadvisor, halaltrip.com as the subject of this research. The analytical method was interactive analysis with three components of analysis, such as data reduction, data presentation, and concluding (Sugiyono, 2011).

\section{Results and Discussion}

Penyengat Island is a part of the administrative Government of Tanjungpinang City. This island is a historic island that has an important role in the rise and fall of the Malay Empire, which previously consisted of the Sultanates of Johor, Pahang, Siak, and Lingga, especially in the southern part of the Malay Peninsula. This important role lasted for 120 years, since the establishment of the Riau Kingdom in 1722, until it was completely taken over by the Dutch Colonial in 1911. Various historical relics have been witnessed until today, such as the graveyards of kings that one of them is Raja Ali Haji tomb, a great mosque of Sultan Riau which was built of egg whites as building glue and fortifications in Kursi Hill. Not only those, but this island also was the birthplace of Malay grammar (the basic grammar of Malay which is later called Indonesian), besides, Penyengat Island is also a National Cultural Heritage Area through the Minister of Education and Culture Decree number 112/M/2018 in 2018 and regulated through the Regional Regulation of Tanjungpinang Government City Number 8, Year 2018 concerning Management of Cultural Tourism of Penyengat Island. But it can be seen that the number of tourist visits to Penyengat Island has decreased. In 2014 the number of visits by 4,877 tourists, while in 2015 was 4,011 tourists and declined in 2016 by 3,421 tourists (Zahra, 2019).

Ministry of Tourism nominated Penyengat Island as a pilot project for the development of halal tourism in the Riau Islands Province. This island has great potential as Religious and cultural tourism destinations which are supported by Muslim community inhabitants make it a great opportunity for this historic island to develop the halal tourism segment. Strategic location adjacent to neighboring Singapore and Malaysia is also considered to be a distinct advantage to attract foreign tourists. Furthermore, offering the concept of "Muslim-friendly

Copyright ( ) 2020. Owned by Author(s), published by Society. This is an open-access article under the CC-BY-NC-SA license. https://doi.org/10.33019/society.v8i1.174

271 
tourism" is a special attraction for Muslim tourists, because it offers the availability of halal food, accommodation based on sharia (some with the concept of family-friendly accommodation), and several facilities supporting Muslim needs. For non-Muslim tourists, halal food is associated with product quality indicated by halal certificates included guarantees of cleanliness, safety, and quality of products in the supply chain (Samori et al., 2016). The development of tourist destinations is not only in the form of regional highlight but also on the potential they have such as art, culture, culinary and local excellence (Anggara et al., 2019). Sumarabawa (2015) as cited in Anggara et al, (2019) stated that the development of tourism potentially requires information on physical and environmental factors that included accessibility, supporting facilities, and infrastructure.

The concept of digital marketing for halal tourism combines the concept as Kaur (2017) puts forward website channels, social media, interesting and mobile-friendly content, with the attributes of halal tourism marketing in the form of easy to search halal products and services; halal assessment and certificate; Halal food features; Halal food restaurant recommendations; improvement of halal tourism experience; Halal as a symbol of culinary differences; the halal aspect at the airport; such as halal services and facilities (Yousaf \& Xiucheng (2018).

By carrying the concept, halal tourism marketing of Penyengat Island can be accessed online; through websites, social media, mobile-friendly with content quality and application. The concept of halal tourism will attract Muslim tourists to visit.

In the development of tourism, marketing is a crucial part of in tourism marketing of Penyengat Island. Promotion is a form of marketing communication, by spreading information, influencing, and reminding target markets for companies (Permana \& Kismartini, 2017). In the disruption era, using technology for tourism marketing is a challenge. The efforts made by the local government in the development of tourism of Penyengat Island are still limited to promotions in the form of providing tourism information centers, annual festivals, heritage market activities, cooperation with travel agents, advertising in the mass media, and billboards in strategic places (Zahra, 2019; Persari et al., 2018). Some activities such as the annual festival are still a mainstay in the promotion of Penyengat Island tourism. Related to technology, promotions are carried out using the Facebook, website, Instagram, YouTube, and e-book travel guides (Persari et al., 2018).

The promotions of Penyengat Island tourism using technology can be found on social media (Facebook, Instagram, YouTube), online booking sites (TripAdvisor, Traveloka), and ebook guides accessed through halaltrip.com. The marketing of Penyengat Island tourism is not only conducted by the local government but also carried out by local communities such as the Penyengat Tourism Awareness Group (Pokdarwis), the Indonesian Enchantment Generation (Genpi) Tanjungpinang, as well as travel agencies that provide tour packages on Penyengat Island. 
Halal Tourism Marketing in the Disruption Era: A Case Study of Penyengat Island in Riau Islands Province

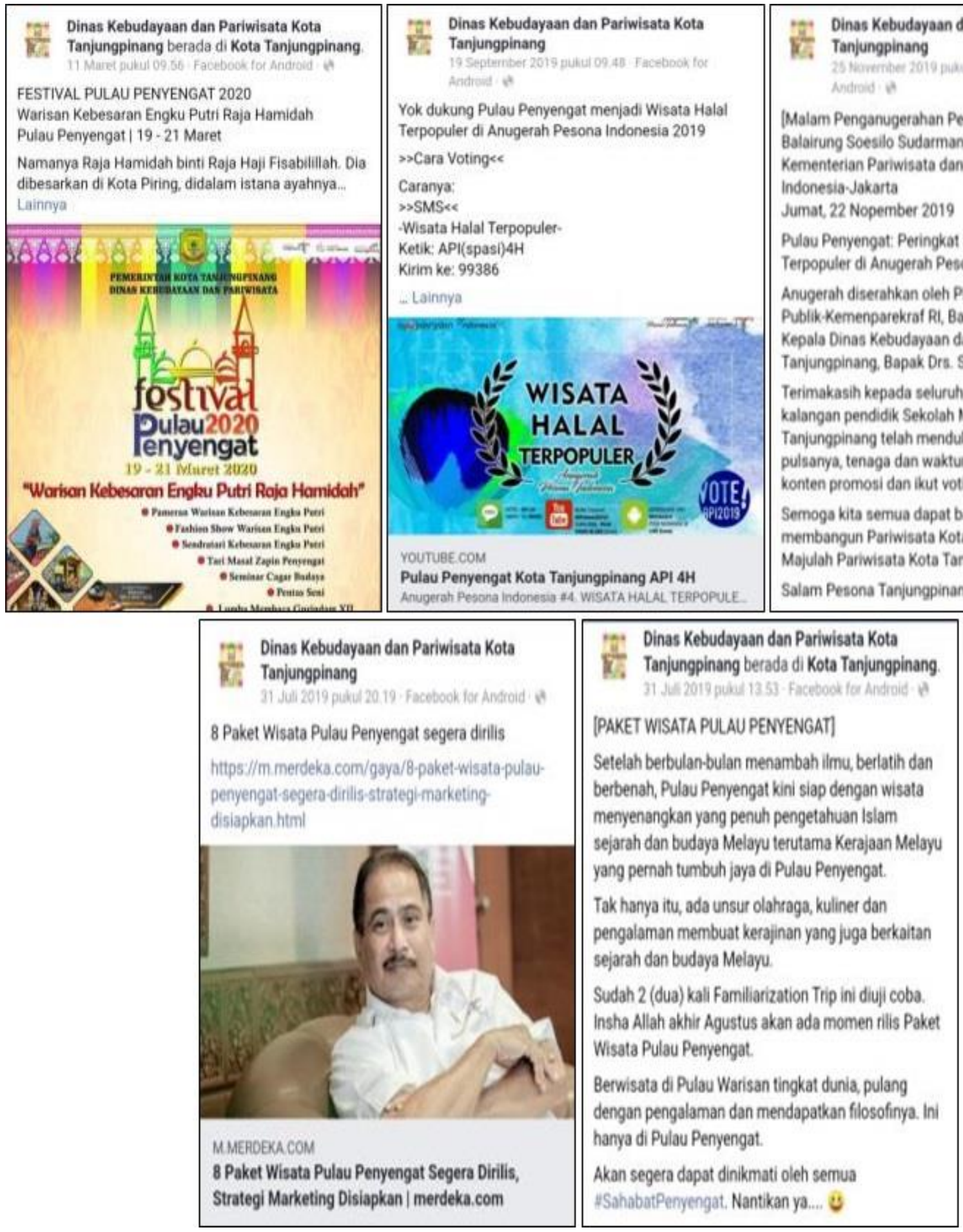

Figure 1. Marketing of Penyengat Island on Facebook

Source: the Facebook account of Local Office of Culture and Tourism, Tanjungpinang City

The Regional Office of Culture and Tourism Tanjungpinang city does not promote Penyengat Island tourism on the website but the office only promotes the island on Facebook with updated information such annual events, Penyengat Island Festival, are still a mainstay in the promotion of Penyengat Island tourism. Likewise with the tour package that was just launched in 2019 to be superior in attracting tourists. However, to establish an image of Penyengat Island as a leading halal tourism destination on Facebook, the office cannot inform as expected.

Copyright (C) 2020. Owned by Author(s), published by Society. This is an open-access article under the CC-BY-NC-SA license. https://doi.org/10.33019/society.v8i1.174 
Halal Tourism Marketing in the Disruption Era:

A Case Study of Penyengat Island in Riau Islands Province

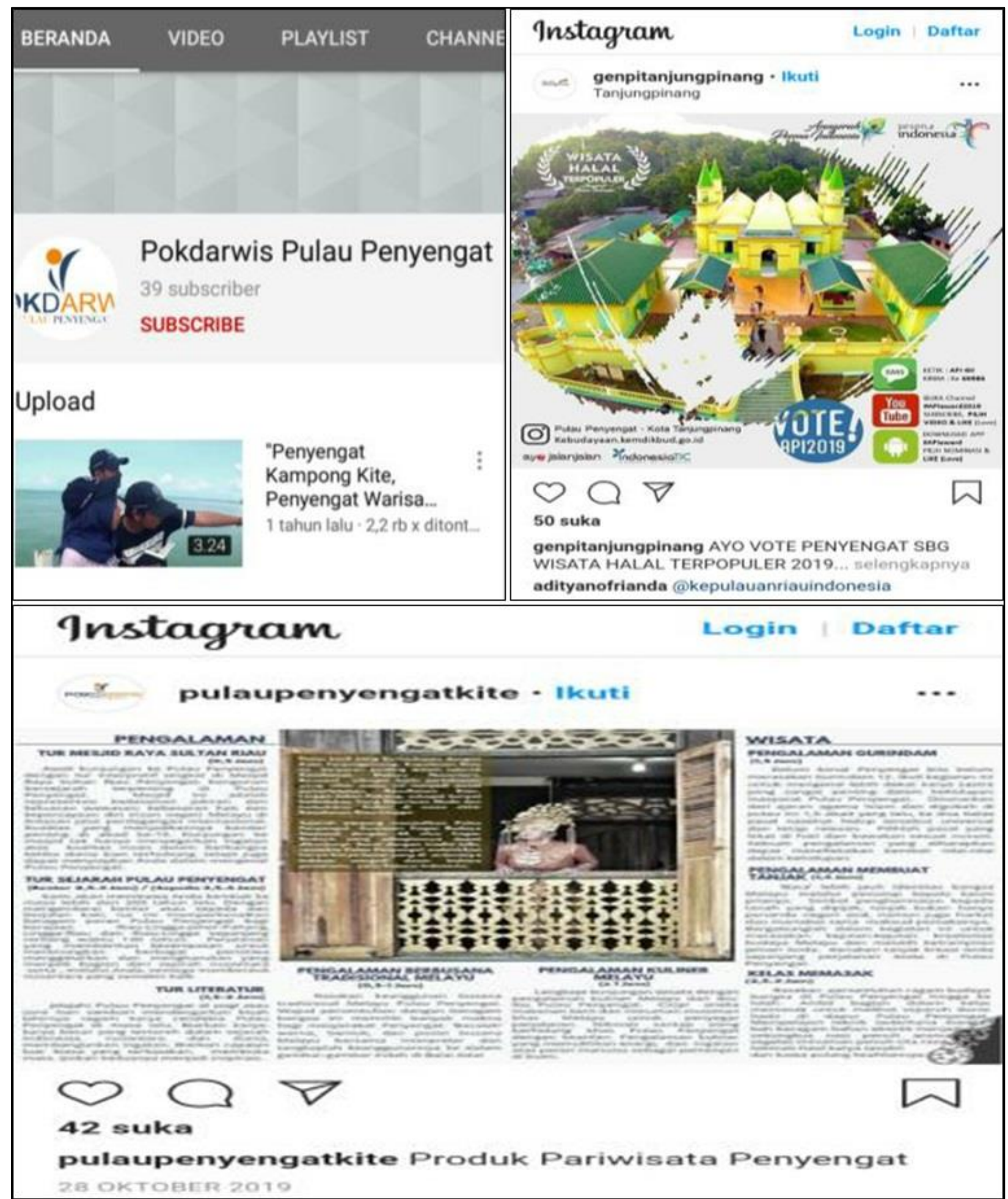

Figure 2. Tourism Marketing of Penyengat Island on Instagram and YouTube

Source: YouTube \& Instagram of Pokdarwis, Penyengat Island and Instagram of Genpi Tanjungpinang

Related to halal tourism marketing, the information only describes the Most Popular Halal Tourism at the Indonesia Enchantment Award 2019. The rest for branding, information on the availability of supporting facilities for Muslim tourists, to attractive tourist attractions is not available yet on the official Facebook account. Yuniningsih \& Suwitri (2017) mentioned that the branding of a tourist destination became one of the efforts to improve the tourism industry in

Copyright (C) 2020. Owned by Author(s), published by Society. This is an open-access article under the CC-BY-NC-SA license. https://doi.org/10.33019/society.v8i1.174 


\section{Halal Tourism Marketing in the Disruption Era: A Case Study of Penyengat Island in Riau Islands Province}

an area. Since each region has a different tourism potential, then followed by geographic tourism development, treatment, and development patterns, the differentiated strategies are needed between regions. Besides, the most potential in tourism marketing is to capture market needs and professionalism of managers to support the adaptive tourism sector. Ideally, the branding process in an area will arise the curiosity to know more about a certain area (Yuniningsih, 2015).

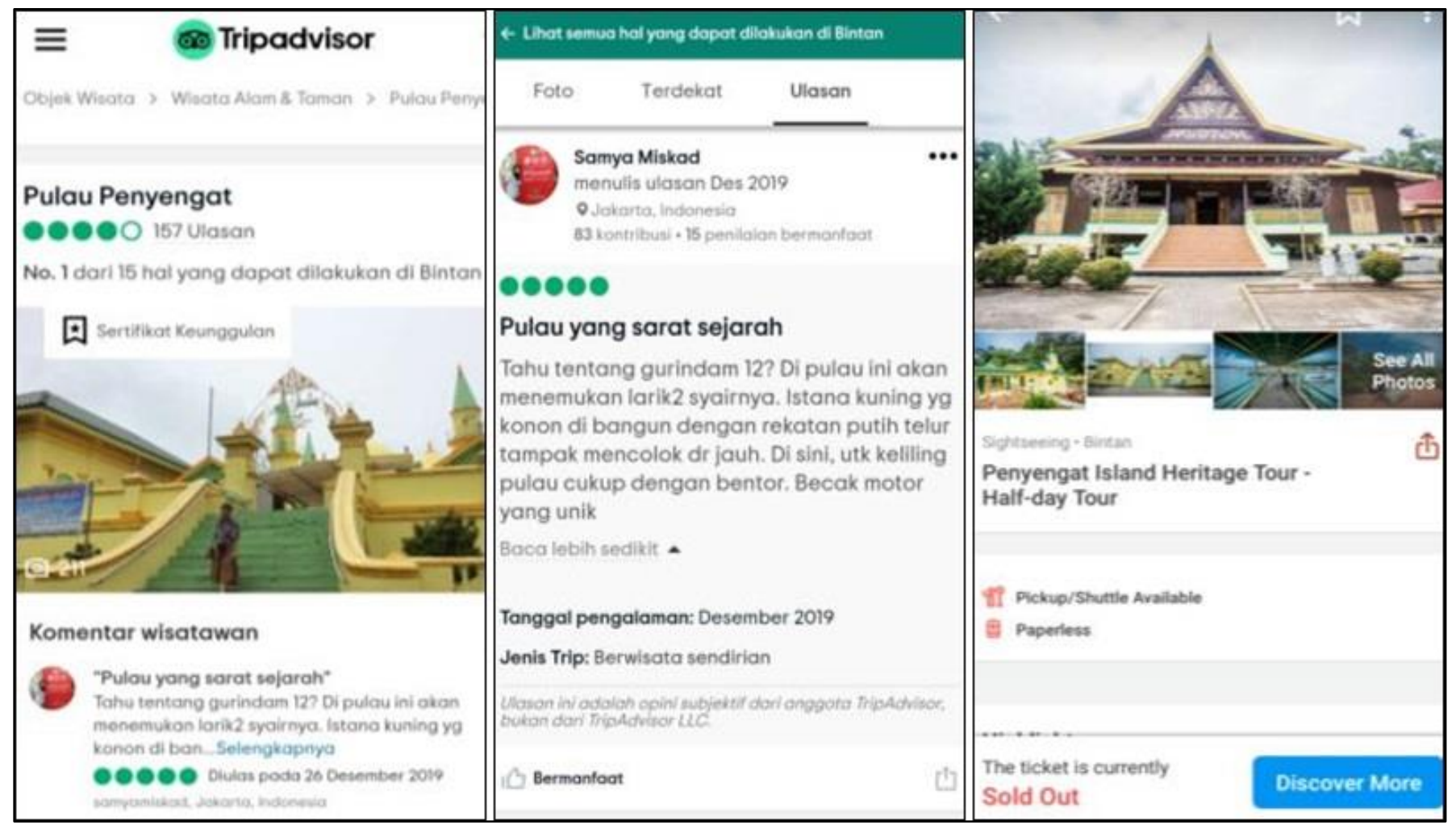

Figure 3. The Reviews and Tour Packages of Penyengat Island Source: Trip Advisor and Traveloka

As a local tourism development community, Pokdarwis of Penyengat Island has been conducting some marketing efforts on Facebook, Instagram, and YouTube. Marketing on YouTube was in 2018 by uploading one video on its YouTube account. This condition is very concern considering YouTube is very effective media to attract tourists if the content is managed in a professional, consistent manner, and always provides the latest and unique information. Beside, Pokdarwis Penyengat Island accounts on Facebook and Instagram are only limited to display tourism promotions in the form of event promotions and tours. The image of Penyengat Island as the leading halal tourism destination has not met a highlight in attracting tourists to visit. Other marketing, Genpi Tanjungpinang, also promoted this island on Instagram. It shows the Penyengat Island Festival which has been held since 2016 and the tour package launched in 2019 where it is still a mainstay that continues to be intensified both online and offline. But these two attractions are still failed to highlight the concept of halal tourism.

Trip Advisor provides a variety of reviews about the experience of traveling on Penyengat Island. It can be referenced for tourists to visit Penyengat Island. The digital market place pages like this one will help tourists in each stage of their traveling experiences, from the planning stage of decision making to the sharing of travel experiences to be a reference for others. However, on this website, the concept of halal tourism in Penyengat Island has not been

Copyright (C 2020. Owned by Author(s), published by Society. This is an open-access article under the CC-BY-NC-SA license. https://doi.org/10.33019/society.v8i1.174 


\section{Halal Tourism Marketing in the Disruption Era: A Case Study of Penyengat Island in Riau Islands Province}

informed seriously because there is no information available on the implementation of halal tourism.

Some reviews about Penyengat Island are mainly around the admiration for religious and cultural tourism offered by this island, but, the detailed description of the facilities available at the tourist destination is not available. If Trip Advisor provides travel reviews to Penyengat Island, Traveloka provides others. This online booking travel site provides a half-day travel tour package to Penyengat Island. The search for Penyengat Island travel in the Traveloka application does not accommodate the availability of travel packages, due to the sold-out information on tourist tour tickets. So the potential tourists only observe some experiences are offered by Penyengat Island tours. It is also the same as this tourism promotion platform because it did not provide enough information about tourist attractions offered on Penyengat Island.
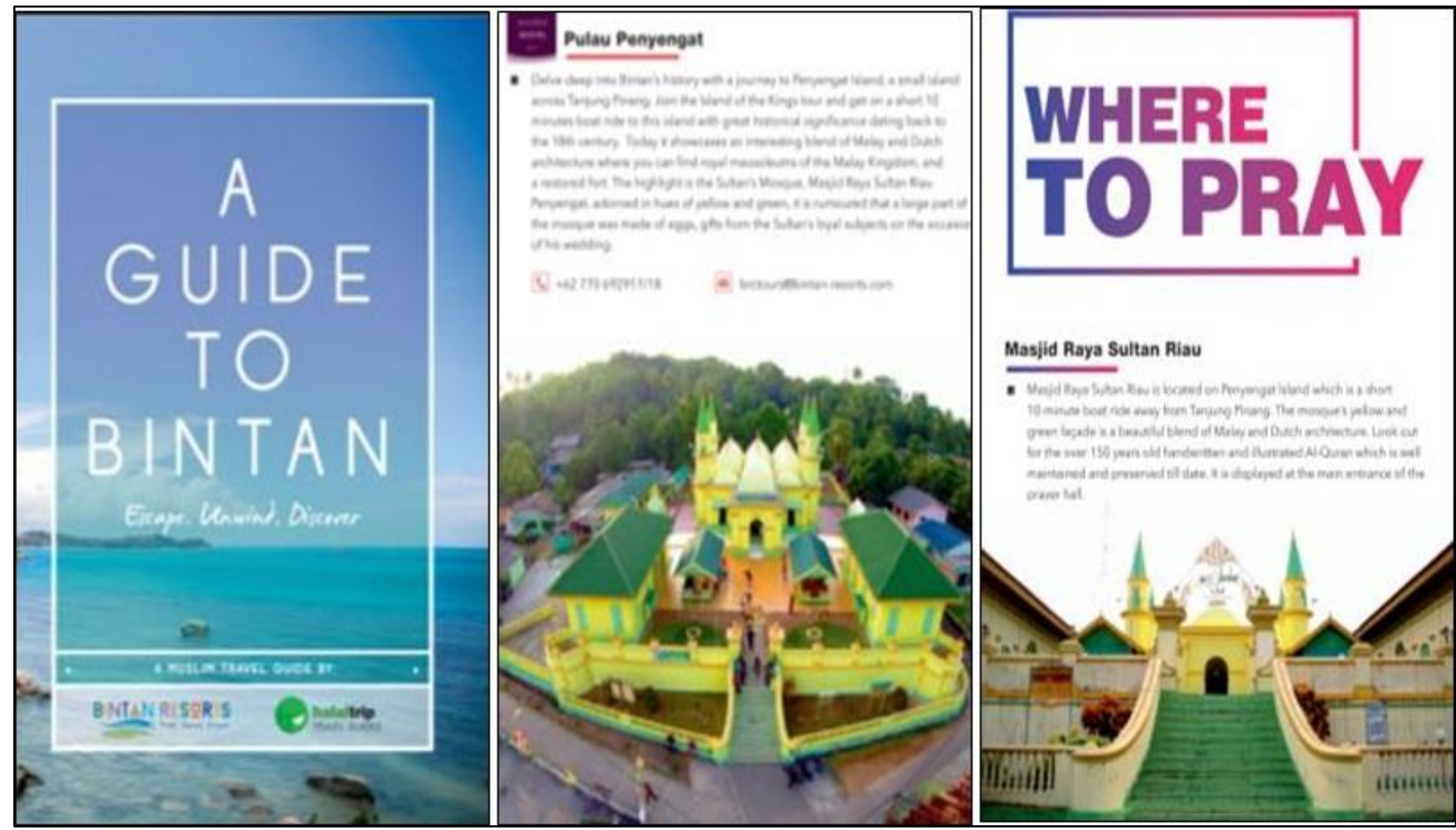

Figure 4. Halal Tourism E-Book Guide on Penyengat Island

Source: halaltrip.com

The e-book of Halal tourism guide book can be accessed via halaltrip.com as a cooperation with the Ministry of Tourism since 2017. This guidebook does not provide completed and detailed information on the implementation of halal tourism on Penyengat Island, because it is a combined tourist guide between Bintan and Penyengat Islands. At the very least, this guide book contains attractions, worship facilities, and the availability of halal food at tourist destinations. But this e-book does describe more about accommodation lists of Muslim tourist needs. Information about halal food is only limited to restaurants that are not located in Penyengat Island. Tourist attractions are still limited to religious and cultural tourism, which has not been touched by innovation as the main asset to attract tourists. This guidebook is available in three languages; English, Arabic, and Mandarin that can accommodate tourists from various parts of the world with different language backgrounds.

Copyright (C) 2020. Owned by Author(s), published by Society. This is an open-access article under the CC-BY-NC-SA license. 


\section{Halal Tourism Marketing in the Disruption Era: A Case Study of Penyengat Island in Riau Islands Province}

The disruption era in tourism is related to the innovations needed to produce unique tourist attractions that are more attractive than others. In the world of tourism, offering something new and unique is an important aspect. Penyengat Island tourism needs to improve its tourist attraction innovation. The lack of tourist attractions as presented on Penyengat Island make the tourists less impressive. Tourists who visit Penyengat Island only enjoy relics of historic sites without adequate information on the history of each site. Innovation in the world of tourism cannot be avoided, because that will be something different in each destination that makes tourists come to visit this tourism destination. The lack of innovation in managing tourist destinations on Penyengat Island makes mostly tourists only visit a few hours. Not many tourists are interested in staying even though lodging facilities are already available on this island since no tourism activities can be enjoyed at night. Halal tourism which began to be implemented on Penyengat Island should bring innovations in providing information on the availability of worship facilities, sanctification facilities, halal food, as well as tourist activities that can be enjoyed by tourists. The provision of this information can be in a mobile-friendly application, as has been implemented of halal tourism destinations in some countries.

Digital marketing dominantly influences the tourism industry because of easy access to information regarding the best deals available to consumers. Consistently, tourists look for the latest information on travel deals, and digital marketing makes content easily searchable and accessible. Tourists determine their travel plans by referring to websites, blogs, comments, and various social media channels to find the best products with reputations and positive reviews. their decisions depend on product identity and other people's reviews about the product. The most important resources that are influential in making global tourist decisions for travel consist of travel review websites, online travel agents, and travel operator websites (Gupta, 2019). Digital innovation in the form of an online travel agent application helps consumers in online booking, travel planning, and travel review, and currently, more than 50 percent of hotel bookings are made online (Jasrotia et al., 2019).

Halal tourism covers a wide range of tourism activities of Muslim tourists, where the trip motivation is not merely in religious activities; even its destination can be in non-Muslim countries (Yousaf \& Xiucheng, 2018). More, Yousaf \& Xiucheng (2018) stated that there are eight dimensions in the marketing of halal tourism, including the ease of finding halal products and services; halal assessment and certificate; Halal food features; Halal food restaurant recommendations; improvement of halal tourism experience; Halal is a symbol of culinary differences; the halal aspect at the airport; Additional halal services and facilities. The promotion of halal tourism is described by Henderson (2003) as cited in Rasul (2019) by stating that "the 'mature and advanced halal industry' and widespread availability of formally certified halal restaurants are showcased, alongside prayer facilities. There are links to the aforementioned halal directory and lists of 'Muslim-friendly' travel agencies, airlines, hotels and resorts, souvenirs, and attractions."

According to Henderson (2003) as cited in Rasul (2019), halal tourism promotion greatly emphasizes aspects of the certified halal food restaurant availability, as well as worship facilities. The rest, travel agents, airlines, hotels and resorts, souvenir places and tourist attractions must also be "Muslim-friendly", to complete the halal instructions available at tourist destinations.

On the marketing side, the image of a tourist destination becomes a prerequisite in the process of designing an effective strategy to offer what is expected by tourists who are considered potential. Another important aspect is meeting the needs of tourists as well as possible. In the case of Muslim tourists, tourism marketing emphasizes halal tourism services

Copyright ( ) 2020. Owned by Author(s), published by Society. This is an open-access article under the CC-BY-NC-SA license. https://doi.org/10.33019/society.v8i1.174 
and products, offers tour packages and destination designs to serve and meet Muslim needs. To strengthen halal tourism, there must be a maximum supply of comfort for Muslim tourists (Halkias et al., 2014).

A series of important aspects in halal tourism marketing has not been promoted in various social media both the government and local communities of Penyengat Island. The social media only describes the content of annual festival events; even the promotion of tour packages is still not intensively carried out. As a digital marketing, media must inform contents that facilitate Muslim tourists to obtain information about the availability of all their needs during the traveling. The presence of social media which only promoted events, marketing of the halal tourism of Penyengat Island will not have a significant impact on describing Penyengat Island as one of the leading halal tourism destinations.

Website and social media are important media in tourism marketing. The tourism website considers as the most important communication tool for marketing tourist destinations in this era. Research showed the use of tourism websites as an important aspect in framing a good tourist destination image, where tourism websites can provide abundant information, showing photos of attractive tourism attractions, and the sales function. In this case, tourism websites provide services as a portal for advertising and marketing $(\mathrm{Wu}, 2018)$.

The regional office of Culture and Tourism, Tanjungpinang city, has not maximized its website to market the halal tourism of Penyengat Island. The website condition is not accessible ultimately will direct tourists to look for tourism information on social media. The official tourism website is to find relevant information about attractions and activities at the destination, as well as facilities and services provided. The site is designed to direct the attention of online visitors to tourist attractions and other facilities such as restaurants and hotels. The regional office of Culture and Tourism should be responsive to this opportunity to develop the halal tourism of Penyengat Island. For Muslim tourists, apart from the places of interest promoted by a tourist destination's website, the most important thing that they attract is the availability of halal food and the appreciation that accompanies their needs. This makes it easy to track halal products and services as an important element in marketing tourism websites for Muslim tourists (Yousaf \& Xiucheng, 2018).

Social media is one of the most significant and effective platforms in digital marketing for the tourism sector. The content provided must be relevant and trusted about the destination in detail, so that the tourists can be generous. Social media that are widely used for digital marketing of Pulau Penyengat tourism have not provided appropriate content to highlight the implementation of halal tourism. It is quite difficult to find information about the organization of halal tourism in Penyengat Island through government social media and local communities, although its use is quite updated. The tourism marketing on social media is only for annual tourism promotion events. Whereas social media is not just a tool to promote content and travel offers, but also must be a communication tool with tourists. The social media users must be a reference destination for Muslim tourists in preparing travel plans, the implication of which is that social media must provide complete guidance on the availability of Muslim travelers' needs while traveling on Penyengat Island, such as worship facilities, guaranteed availability of halal food, toilets completed restroom facility for Muslims, "Muslim-friendly" lodging, shariacompliant travel experience, and other supporting matters. Social media acts as a knowledgesharing platform through users who share travel experiences, valuable reciprocal responses, write reviews, and share photos that can attract the attention of even more people (Gupta, 2019).

Copyright ( ) 2020. Owned by Author(s), published by Society. This is an open-access article under the CC-BY-NC-SA license. https://doi.org/10.33019/society.v8i1.174 


\section{Halal Tourism Marketing in the Disruption Era: A Case Study of Penyengat Island in Riau Islands Province}

The poor halal tourism marketing of Penyengat Island as a result of the local government and related stakeholders in creating innovative tourist attractions. According to Jones (2003) as cited in Wilfridus (2010), innovation is an organizational process of using expertise and resources to develop new products and services or to develop new production and operating systems so that the organization can provide higher satisfaction to consumers (Yuniningsih, 2015). In tourism, innovation is the result of creating new products or modifying existing tourism products (Belova \& Kropinova, 2015). So far, both the local government and communities have created innovations such as promoting tourism materials included new tour packages launched in 2019, the annual Penyengat Island Festival as well as a heritage market initiated by Genpi Tanjungpinang. The three activities have not shown the optimal results to attract tourists to visit this Island. The tour packages that must be ordered through Pokdarwis, the heritage market which is only held on Sundays, and the annual festival that contains several activities that do not attract a wider tourist market share, showing that innovation tourist attraction that seeks to be created cannot "cover" tourism of Penyengat Island into something attractive. Whereas, tourist attraction innovation becomes an important thing in tourism marketing efforts since it is the key to attracting tourists. The managed marketing tourism using digital channels will result beyond the expectations unless the tourist attraction offered is less attractive.

The advance of technology contributes to the provision of smartphone applications in the halal tourism industry which certainly makes holidays more comfortable and "Muslimfriendly". This strategy has been one of the tourist attractions for Muslim tourists to visit; also, it will be adding value in marketing destinations and developing halal tourism. Technological innovations will be an additional point in strengthening the halal tourism industry on Penyengat Island if it is supported by human resources and cooperated with related stakeholders. The ease of tourism information access as described above is needed by Muslim tourists for traveling plans to a tourism destination. Halal Navi is an example of a smartphone application that helps Muslim tourists, especially in Japan to find halal food restaurants and provides some reviews from consumers (Samori et al., 2016). Similar to Japan, Thailand took the initiative to launch a smartphone application "Muslim-friendly" to encourage the tourism industry in Thailand (Battour \& Ismail, 2016). The application helps tourists find shopping centers and hotels with worship facilities and halal food restaurants. This application is available in English and Thai and will be upgraded to Arabic and Indonesian. The app is available on Android and iOS. Stephenson (2014) as cited in Battour \& Ismail (2016) stated that applications as mentioned above will make it easier for Muslim tourists to find hospitality products and services as "halal-friendly", such as hotels, destination guides, vacation packages, guides at airports and halal restaurants. Predictably, non-Muslim countries targeting Muslim tourist visits will develop their applications to make their country as "Muslim-friendly".

\section{Conclusion}

The disruption era transforms the system into the tourism industry. The technology use is crucial in each tour stage. The tourist behavior changes such as planning their tourist trips have encouraged the tourism industry in providing easy access to information channels using information technology. Halal tourism of Penyengat Island faces some challenges in its development, considering this era has transformed tourism marketing strategies rely on the internet, social media, and the availability of mobile-friendly applications. Tough, the digital marketing of halal tourism development on Penyengat Island has not been taken seriously yet. The use of social media and digital market place pages does not show an effort in branding

Copyright (C) 2020. Owned by Author(s), published by Society. This is an open-access article under the CC-BY-NC-SA license. https://doi.org/10.33019/society.v8i1.174 
Penyengat Island as a leading halal tourist destination in the Riau Islands Province. The poor of advocacy of the applicable concept of halal tourism, the poor of information on the available supported facilities, and the poor of innovative tourist attractions make tourism marketing through digital channels beyond the expectations. Based on the conclusions, some suggestions are as follows:

a. Enabling the constantly updated social media and websites as digital marketing tools and providing some interesting content;

b. Branding Penyengat Island as halal tourism through digital channels, and containing information about the availability of Muslim tourist needs;

c. Presenting the innovation of tourist attractions on Penyengat Island.

\section{Acknowledgment}

The authors are grateful to express gratitude to all of those who have had the pleasure to work during this research conducted.

\section{Declaration of Conflicting Interests}

The authors declared no potential conflicts of interest concerning the research, authorship, and/or publication of this article.

\section{References}

Anggara, H. D., Dewantoro, D., \& Kismartini, K. (2019). Keberadaan Transportasi Online Dalam Pengembangan Pariwisata Kota Pekalongan. Conference on Public Administration and Society "Collaborative Governance dalam Pengembangan Pariwisata di Indonesia," 161-170. Semarang, Indonesia: $\quad$ Universitas

Diponegoro. http://proceedings.undip.ac.id/index.php/copas/article/view/27/11

Badan Pusat Statistik. (2020, April). Statistik Indonesia 2020 (1101001). Retrieved from https:/ / www.bps.go.id/publication/2020/04/29/e9011b3155d45d70823c141f/statistikindonesia-2020.html

Balasubramanian, K., \& Ragavan, N. A. (2019). What are the key challenges faced by the Malaysian hospitality and tourism industry in the context of industrial revolution 4.0? Worldwide Hospitality and Tourism Themes, 11(2), 194-203. https://doi.org/10.1108/whatt11-2018-0079

Battour, M., \& Ismail, M. N. (2016). Halal tourism: Concepts, practices, challenges and future. Tourism management perspectives, 19, 150-154. https://doi.org/10.1016/j.tmp.2015.12.008

Belova, A. V., \& Kropinova, E. G. (2015). New Forms of Innovative Tourism Products as a Result of the Interaction of History, Culture and Tourism. Mediterranean Journal of Social Sciences, 6(6 S7), 41-45. https:/ / doi.org/10.5901/mjss.2015.v6n6s7p41

Buhalis, D. (2019). Technology in tourism-from information communication technologies to eTourism and smart tourism towards ambient intelligence tourism: a perspective article. Tourism Review, 75(1), 267-272. https://doi.org/10.1108/tr-06-2019-0258

Cox, C., \& Wray, M. (2011). Best Practice Marketing for Regional Tourism Destinations. Journal of Travel $\mathcal{E} \quad$ Tourism Marketing, 28(5), 524-540. https:/ / doi.org/10.1080/10548408.2011.588112

DinarStandard, \& Dubai International Financial Centre. (2018). State of the Global Islamic Economy Report 2018/19. Thomson Reuters. Retrieved from https://haladinar.io/hdn/doc/report2018.pdf 
Gupta G. (2019). Inclusive Use of Digital Marketing in Tourism Industry. In: Satapathy S., Bhateja V., Somanah R., Yang XS., Senkerik R. (eds). Information Systems Design and Intelligent Applications. Advances in Intelligent Systems and Computing, vol 862. Springer, Singapore. https://doi.org/10.1007/978-981-13-3329-3_38

Hadi, S. (1995). Statistik II. Jakarta: PT. Rineka Cipta.

Halkias, D., Pizzurno, E., De Massis, A., \& Fragoudakis, M. (2014). Halal Products And Services In The Italian Tourism And Hospitality Industry: Brief Case Studies Of Entrepreneurship And Innovation. Journal of Developmental Entrepreneurship (JDE), 19(02), 1-12. https://doi.org/10.1142/S1084946714500125

Happ, É., \& Ivancsó-Horváth, Z. (2018). Digital tourism is the challenge of future-a new approach to tourism. Knowledge Horizons. Economics, 10(2), 9-16. https://www.orizonturi.ucdc.ro/arhiva/KHE\%20nr.\%202\%20-

\%202018/1.\%20DIGITAL\%20TOURISM\%20IS\%20THE\%20CHALLENGE\%20OF\%20FUT URE.pdf

Hidayat, Y. D. (2019). Disrupsi Digital dan Pariwisata di Toraja. In BBPSDMP Kominfo Makassar \& Fakultas Ilmu Komputer UMI Makassar (Eds.), Seminar Nasional Komunikasi dan Informatika \#3 "Membangun Ekosistem Digital di Era Industri 4.0" (pp. 168-178). Makassar, Indonesia: Kementerian Komunikasi dan Informatika Republik Indonesia. https://jurnal.kominfo.go.id/index.php/snki/issue/viewFile/212/32

Hsu, A. Y. C., King, B., Wang, D., \& Buhalis, D. (2016). In-destination tour products and the disrupted tourism industry: progress and prospects. Information Technology $\mathcal{E}$ Tourism, 16(4), 413-433. https:/ / doi.org/10.1007/s40558-016-0067-y

Idris, J., \& Rahman, S. S. A. (2018). Analyzing marketing macro environment of Islamic tourism industry in Malaysia. The 5thInternational Conference on Management and Muamalah "Empowering Knowledge Sharing Culture in Management and Muamalah," 435-442. Malaysia. Retrieved from http://conference.kuis.edu.my/icomm/5th/images/e-proceeding/IC041.pdf

Indonesiatravel.news. (2019, February 18). Pulau Penyengat Jadi Pilot Project Wisata Halal. Retrieved from https://www.indonesiatravel.news/pariwisata/pulau-penyengat-jadipilot-project-wisata-halal/

Jasrotia, S. S., Mishra, H. G., \& Koul, S. (2019). Brick or Click? Channel Choice Disruptions in Travel Industry. Asia-Pacific Journal of Management Research and Innovation, 15(1-2), 16-26. https:// doi.org/10.1177/2319510x19829308

Kaur, G. (2017). The importance of digital marketing in the tourism industry. International Journal of Research-Granthaalayah, 5(6), 72. https://doi.org/10.5281/zenodo.815854

Kementerian Koordinator Bidang Kemaritiman dan Investasi Republik Indonesia. (2019, April 19). 5 Tahun Kembangkan Pariwisata Halal, Indonesia Akhirnya Raih Peringkat Pertama Wisata Halal Dunia 2019. Retrieved from https://maritim.go.id/5-tahun-kembangkanpariwisata-halal-indonesia-akhirnya-raih-peringkat-pertama-wisata-halal-dunia-2019/

Liputan6.com. (2019, February 13). Industri Pariwisata Sumbang Devisa Tertinggi Setelah CPO.

Retrieved from https://www.liputan6.com/bisnis/read/3894129/industri-pariwisatasumbang-devisa-tertinggi-setelah-cpo

MasterCard, \& CrescentRating. (2018, October). Digital Muslim Travel Report 2018. Retrieved from https:/ / www.crescentrating.com/reports/digital-muslim-travel-report-2018.html

Musthofa, B. M. (2019). Strategi Adaptasi Destinasi Wisata Budaya Di Era Disrupsi Teknologi. In Program Pendidikan Vokasi Universitas Halu Uleo (Ed.), Seminar Nasional Teknologi Terapan: Inovasi dan Rekayasa Teknologi untuk Memperkuat Daya Saing Bangsa (pp. 421-426).

Copyright (C) 2020. Owned by Author(s), published by Society. This is an open-access article under the CC-BY-NC-SA license. https://doi.org/10.33019/society.v8i1.174 
Kendari, Indonesia: Forum Pendidikan Tinggi Vokasi Indonesia. Retrieved from http://ojs.uho.ac.id/index.php/snt2bkl/article/viewFile/9877/7109

Permana, Z. A., \& Kismartini, K. (2017). Implementation of Tourism Promotion Policy in Semarang City. Journal of Public Policy and Management Review, 6(4), 349-361. https:// doi.org/10.14710/jppmr.v6i4.17856

Persari, D., Heriyanto, M., \& Yuliani, F. (2018). Implementasi Strategi Pengembangan Kepariwisataan. JIANA (Jurnal Ilmu Administrasi Negara), 15(1), 104-109. https://jiana.ejournal.unri.ac.id/index.php/JIANA/article/view/6785

Pujayanti, D. A. (2020). Industri Halal sebagai Paradigma bagi Sustainable Development Goals di Era Revolusi Industri 4.0. Youth $\mathcal{E}$ Islamic Economic, 1(01), 20-33. http://jurnalhamfara.ac.id/index.php/yie/article/view/48

Putra, I. D. G. A. D. (2018). Evoking traditions and creating uniqueness: traditional settlements and tourism in disruptive era. 4th International Conference on Indonesian Architecture and Planning "Design and Planning in Disruptive Era," 308-315. Yogyakarta, Indonesia. Retrieved from https://simdos.unud.ac.id/uploads/file_penelitian_1_dir/bb550c51f37ad137bb881914fb9ef108.pd $\mathrm{f}$

Purcărea, T., \& Purcărea, A. (2017). Services Marketing in the Era of Disruption and Digital Transformation. Romanian Economic and Business Review, 12(4), 7-26. http://www.rebe.rau.ro/RePEc/rau/journl/WI17/REBE-WI17-A1.pdf

Rasul, T. (2019). The trends, opportunities and challenges of halal tourism: a systematic literature review. Tourism Recreation Research, 44(4), 434-450. https:/ / doi.org/10.1080/02508281.2019.1599532

Ratu, C., \& Adikampana, I. M. (2016). Strategi Pemasaran Desa Wisata Blimbingsari Kabupaten $\begin{array}{lllll}\text { Jembrana. Jurnal Destinasi } & \text { Pariwisata, }\end{array}$ https://doi.org/10.24843/jdepar.2016.v04.i01.p10

Razzaq, S., Hall, C. M., \& Prayag, G. (2016). The capacity of New Zealand to accommodate the halal tourism market - or not. Tourism Management Perspectives, 18, 92-97. https://doi.org/10.1016/j.tmp.2016.01.008

Rohimah, A., \& Romadhan, M. I. (2019). Marketing Communication Strategy Of Halal Tourism Around Gus Dur's Cemetery In Jombang. Inject (Interdisciplinary Journal of Communication), 4(1), 1. https:/ / doi.org/10.18326/inject.v4i1.1-14

Roziqin, A. (2019). Dinamika Pengembangan Batik Tulis Lasem di Era Disruption (Thesis). Universitas Gadjah Mada. Retrieved from http:/ / etd.repository.ugm.ac.id/penelitian/detail/169961

Samori, Z., Md Salleh, N. Z., \& Khalid, M. M. (2016). Current trends on Halal tourism: Cases on selected Asian countries. Tourism Management Perspectives, 19, 131-136. https://doi.org/10.1016/j.tmp.2015.12.011

Sigala, M. (2018). New technologies in tourism: From multi-disciplinary to anti-disciplinary advances and trajectories. Tourism Management Perspectives, 25, 151-155. https:/ / doi.org/10.1016/j.tmp.2017.12.003

Sugiyono. (2011). Metode Penelitian Kuantitatif, Kualitatif dan RED. Bandung: Penerbit Alfabeta.

Wahidati, L., \& Sarinastiti, E. N. (2018). Perkembangan Wisata Halal di Jepang. Jurnal Gama Societa, 1(1), 9-19. https://journal.ugm.ac.id/jgs/article/view/34043

Wu, G. (2018). Official websites as a tourism marketing medium: A contrastive analysis from the perspective of appraisal theory. Journal of Destination Marketing $\mathcal{E}$ Management, 10, 164171. https:/ / doi.org/10.1016/j.jdmm.2018.09.004 
Yousaf, S., \& Xiucheng, F. (2018). Halal culinary and tourism marketing strategies on government websites: A preliminary analysis. Tourism Management, 68, 423-443. https://doi.org/10.1016/j.tourman.2018.04.006

Yuniningsih, T. (2015). Inovasi Kebijakan Pariwisata Kota Semarang Menyongsong Masyarakat Ekonomi ASEAN Melalui Strategi Promosi “City Branding. Seminar Nasional Administrasi Publik 2015 "Peluang dan Tantangan Indonesia Menyongsong ASEAN Economic Community melalui Inovasi Kebijakan dan Manajemen Publik," 87-97. Semarang, Indonesia. Retrieved from Un_Musamus_2015_P.pdf

Yuniningsih, T., \& Suwitri, S. (2017). Partisipasi Masyarakat Dalam Pengembangan City Branding Kota Semarang Jawa Tengah Indonesia. Seminar Nasional dan Call for Paper Fakultas Ilmu Sosial dan Ilmu Politik Universitas Muhammadiyah Sidoarjo "City Branding \& Tourism Policy Based on Cultural Wisdom in Indonesia," 165-174. Banyuwangi, Indonesia. https:// doi.org/10.21070/semnasfi.v1i1.1140

Zahra, S. K. (2019). Strategi Pemerintah dalam Pengembangan Potensi Pariwisata: Studi tentang Strategi Dinas Kebudayaan dan Pariwisata dalam Pengelolaan Kawasan Wisata Pulau Penyengat Kecamatan Tanjungpinang Kota Tanjungpinang Periode 2014-2016 (Thesis). Universitas Padjadjaran.

\section{About the Authors}

1. Riska Destiana, a graduate student at Master of Public Administration, Department of Public Administration, Faculty of Social and Political Sciences, Diponegoro University, Indonesia.

E-Mail: destiana.riska1812@gmail.com

2. Kismartini, obtained her Doctoral degree from Brawijaya University, in 2012. The author is an Associate Professor at the Department of Public Administration, Faculty of Social and Political Sciences, Diponegoro University, Indonesia.

E-Mail: kismartini@live.undip.ac.id 